\title{
AMINO ACID CONTENT AND NUTRITIVE VALUE OF TUNA (TIUNNUS SP.) FISHMEALS RELATIVE TO THEIR CRUDE-PROTEIN CONTENT
}

Little information is available concerning the essential amino acid content and biological value of tuna fishmeals. An average crude protein content of 57.4 percent for tuna fishmeal was reported for the United States by the National Research Council (see footnote, table 1). In contrast, 18 samples of tuna fishmeals produced in Puerto Rico, obtained periodically between 1966-69 and analyzed in our laboratory, had an average protein content of 47.84 percent ( $4 \overline{5} .25$ to 56.31 percent) (table 1 ), which is considerably below the U.S. average. This may be because more muscle is removed locally from the scrap for pet food.

In an effort to determine the nutritive value of locally-produced fishmeals, two tuna samples with a 9.8 percent difference in crude protein content were analyzed.

The chemical and amino acid compositions are shown in table 1. Attention is called to the fact that when expressed as percentages of the crude protein present they were 7.01 and 6.68 for lysine, and 2.59 and 2.64 for methionine, for samples 1 and 2, respectively. The close proportional relationship found in samples having a 9.8 percent difference in crude-protein content, but analyzed at the same time by identical methods in the same laboratory, should be tested further with more samples of variable crude-protein content.

Table 2 shows the data obtained from a chick bioassay, conducted by the Technological Laboratory of the Bureau of Commercial Fisheries, U.S. Department of Interior, to evaluate the protein quality of the tuna fishmeal samples 1 and 2 described in table 1 .

Feed utilization by the experimental groups, identical regardless of the

TAnLE 1.-Chemical and amino acid composition of locally-produced tuna fishmeals ${ }^{1}$

\begin{tabular}{|c|c|c|c|c|c|}
\hline \multirow{2}{*}{ Item } & \multicolumn{5}{|c|}{ Composition, percent air dry basis } \\
\hline & Sample 1 (MI) & Sample $2(\mathrm{P})$ & $\underset{\text { average! }}{\operatorname{lan} \text { Camp }}$ & $\begin{array}{l}\text { Puerto Rico } \\
\text { average }^{2}\end{array}$ & $\begin{array}{c}\text { United States } \\
\text { average }^{3}\end{array}$ \\
\hline \multicolumn{6}{|c|}{ Chemical } \\
\hline Moisture & 5.99 & 9.38 & 9.50 & 7.98 & 13.00 \\
\hline Crude protein & 54.07 & 44.30 & (j1. 40 & 47.98 & 57.40 \\
\hline Fat & 4.68 & 6.67 & 7.00 & 4.57 & 8.90 \\
\hline Ash & 18.62 & 15.75 & 20.00 & 24.03 & 19.00 \\
\hline Calcium & 8.12 & 9.99 & 4.00 & 7.63 & 5.32 \\
\hline Phosphorus & 4.20 & 4.97 & 2.50 & 4.29 & 3.07 \\
\hline Sodium chloride & - & - & 1.00 & 1.22 & - \\
\hline
\end{tabular}


TABLE 1.-Conlinued

\begin{tabular}{l|c|c|c|c|c}
\hline \multirow{2}{*}{ Item } & \multicolumn{5}{c}{ Composition, percent air dry basis } \\
\cline { 2 - 6 } & Sample 1 (M) & Sample 2 (P) & $\begin{array}{c}\text { Van Camp } \\
\text { average }\end{array}$ & $\begin{array}{c}\text { Puerto Rico } \\
\text { average }\end{array}$ & $\begin{array}{c}\text { United States } \\
\text { average }\end{array}$ \\
\hline \multicolumn{5}{c}{ Amino acid } \\
\hline Lysine & 3.79 & 2.96 & 5.10 & 3.38 & 6.19 \\
Tryptophane & - & - & 0.70 & - & 0.90 \\
Methionine & 1.40 & 1.17 & 1.63 & 1.29 & 1.70 \\
Cystine & - & - & 1.04 & - & - \\
Threonine & 2.17 & 1.79 & 2.35 & 1.98 & - \\
Leucine & 3.69 & 2.92 & 4.43 & 3.31 & - \\
Isoleucine & 2.26 & 1.78 & 3.17 & 2.02 & - \\
Histidine & 2.00 & 1.41 & 1.51 & 1.71 & - \\
Glycine & 4.36 & 4.39 & 4.14 & 4.37 & - \\
Valine & 2.76 & 2.14 & 3.78 & 2.45 & 2.20 \\
Phenylalanine & 2.07 & 1.67 & 2.46 & 1.87 & - \\
Tyrosine & 1.70 & 1.31 & - & 1.50 & - \\
Arginine & 3.32 & 2.99 & 5.24 & 3.16 & 6.99 \\
Others & 19.63 & 10.75 & 25.85 & 18.19 & - \\
\hline
\end{tabular}

1 Compiled from Van Camp-Laboratory Analysis, unpublished, 1966.

2 Based on data from 18 locally-produced samples obtained periodically between $1966-69$.

${ }^{3}$ Based on data from National Research Council Publication 1232, p. 63, 1964.

${ }^{4}$ Determined by a method using the Techicron autoanalizer. Acknowledgement for the amino acid analysis is given to Robert $R$. Kifer and Paul Bauersfeld, Technological Laboratory, Bureau of Commercial Fisheries, College Park, Md. 20740.

${ }^{5}$ Includes alanine, serine, proline, glutamic and aspartic acids.

TABLE 2.-Rate of gain and ulilization of feed by chichs used in the bioassay to compare the nutritional value of two samples of tuna fishmeal

\begin{tabular}{c|c|c}
\hline Sample & Rate of gain & Utilization of feed \\
\cline { 2 - 3 } & Percent of positive control & Gain/feed/ratio \\
Pusitive control ${ }^{2}$ & 100 & 1.57 \\
Negative nitrogen control ${ }^{3}$ & 62 & 1.84 \\
Tuna 1 $(12.5 \text { parts } / 100)^{4}$ & 84 & 1.69 \\
Tuna 1 $(17.1 \text { parts } / 100)^{4}$ & 85 & 1.69 \\
Tuna 2 $(12.5 \text { parts } / 100)^{4}$ & 92 & 1.68 \\
\hline
\end{tabular}

1 Soybean meal semi-purified diets identical in nitrogen, calcium, phosphorus and caloric contents were used in the bioassay that lasted 3 weeks.

2 A methionine-supplemented, semi-purified soybean meal diet.

${ }^{3}$ Same as positive control without supplementary methionine.

4 Each tuna meal replaced a quantity of the soybean to the calcium restriction. Under this restriction, tuna meal 1 comprised 17.1 parts $/ 100$, whereas tuna meal 2 was restricted to 12.5 parts/100. For comparative purposes tuna meal 1 was also fed at the 12.5 parts $/ 100$ level. 
tuna meal level of the diets, was superior to the negative controls and inferior to the positive control. The identical rates of gain of the groups receiving sample 1 (54.08 percent crude protein) were but slightly inferior to those of the group receiving sample 2 (44.30 percent crude protein).

Further studies should be conducted with practical-type diets based on corn to determine if tuna fishmeals varying considerably in crude-protein content provide enough sulfur-containing amino acids (methionine plus cystine) to permit maximum growth and optimum utilization of feed by the birds when compared with a methionine-supplemented control. 